\title{
PENGARUH KECERDASAN EMOSI DAN POLA ASUH OTORITATIF TERHADAP PERILAKU PROSOSIAL ANAK USIA 9-11 TAHUN PADA SISWA SD NEGERI 2 PASSO KECAMATAN BAGUALA DI KOTA AMBON
}

\section{Malitsa Giovanna Tahitu}

\author{
Dosen Institut Agama Kristen Negeri Ambon \\ Email:echa.tahitoe@gmail.com
}

\begin{abstract}
This study aims toexamine the influence of emotional intelligence and authoritative parenting simultaneously towards prosocial behavior of children aged 9-11 years at SD Negeri 2 Passo, Baguala Subdisctrict, Ambon City. The data was collected through questionaires distribution. The samples are the 107 students aged 9-11 years old. Based on the multiple regression analysis using SPSS windows version 16.0, it is found: $F=8617$ at $p$ $=0.000(\mathrm{p}<0.05)$. Therefore, it can be concluded that simultaeously, emotional intelligence variable and authoritative parenting have significant influence on prosocial behaviour. Effective contribution of these two variables $\mathrm{X}$ to $\mathrm{Y}$ is shown on the price of $\mathrm{R}^{2}=0.142$, which indicatesthat emotional intelligence and authoritative parenting contributing an impact of $14,2 \%$ on prosocial behavior. Partially, the result of statistical calculation shows prices at $\mathrm{t}=1.901$ at $\mathrm{p}=0.060(\mathrm{p}>0.05)$ for influence between variables emotional intelligence with prosocial behavior. Price $t=2.961$, and $p=0.004(p<0.05)$ for impacts between authoritative parenting and prosocial behavior. It means that, in partial,emotional intelligence variable does not affect on prosocial behavior significantly. While, the authoritative parenting variable influences, significantly, on prosocial behavior.
\end{abstract}

Keywords: Emotional intelligence, Authoritative parenting, Prosocial behavior

\begin{abstract}
Abstrak
Penelitian ini bertujuan untuk melihat pengaruh kecerdasan emosi dan pola asuh otoritatif secara simultan terhadap perilaku prososial anak usia 9 - 11 tahun pada SD Negeri 2 Passo Kecamatan Baguala di Kota Ambon. Teknik pengumpulan data dilakukan dengan cara menyebarkan angket. Sampel penelitian adalah siswa yang berusia $9-11$ tahun di SD Negeri 2 Passo yang berjumlah 107 siswa. Hasil penelitian dengan analisis regresi berganda melalui program SPSS windows versi 16.0, menunjukan harga $F=8.617$ pada $p=0.000(p<0.05)$. Sehingga dapat disimpulkan bahwa secara simultan variabel kecerdasan emosi dan pola asuh otoritatif berpengaruh yang sangat signifikan terhadap perilaku prososial. Sumbangan efektif kedua variabel $\mathrm{X}$ terhadap $\mathrm{Y}$ ditunjukan dari harga $\mathrm{R}^{2}=0.142$ yang berarti variabel kecerdasan emosi dan pola asuh otoritatif secara bersama memberikan pengaruh sebesar $14,2 \%$ terhadap perilaku prososial. Secara parsial, hasil perhitungan statistik menunjukan harga $\mathrm{t}=1.901$ pada $\mathrm{p}=0.060(\mathrm{p}>0.05)$ untuk pengaruh antara variabel kecerdasan emosi dengan perilaku prososial. Harga $t=2.961$ pada $p=0.004(p<0.05)$ untuk pengaruh antara pola asuh otoritatif dengan perilaku prososial. Artinya, secara parsial variabel kecerdasan emosi tidak berpengaruh secara signifikan terhadap perilaku prososial dan variabel pola asuh otoritatif berpengaruh secara signifikan terhadap perilaku prososial
\end{abstract}

Kata Kunci: perilaku prososial, kecerdasan emosi, pola asuh otoritatif. 


\section{PENGANTAR}

Manusia adalah makhluk sosial, yang berarti bahwa manusia tidak dapat hidup tanpa hadirnya orang lain dilingkungan sekitarnya. Dalam proses hidup, manusia selalu membutuhkan orang lain mulai dari lingkungan yang paling dekat yaitu keluarga hingga sampai pada orang yang mungkin tidak kenal sama sekali. Seiring dengan berjalannya waktu, kepedulian seseorang terhadap orang lain dan lingkungan di sekitarnya menjadi menurun. Dapat dikatakan bahwa manusia sekarang menjadi lebih menggunakan konsep hidup yang terlebih dahulu diri sendiri baru kemudian menyenangkan orang lain. Hal ini mengakibatkan manusia menjadi makhluk yang individual. Ada banyak faktor yang mempengaruhi menurunnya kepedulian seseorang terhadap orang lain maupun lingkungan sekitarnya.

Sears, Freedman, dan Peplau' ${ }^{1}$, melalui penelitiannya, menemukan bahwa beberapa orang tetap memberikan bantuan kepada orang lain meskipun kondisi situasional menghambat usaha pemberian bantuan tersebut, sedangkan yang lain tidak memberikan bantuan sama sekali meskipun berada dalam kondisi yang baik. Sesuai dengan penelitian yang dilakukan oleh Foa dan Foa $^{2}$, sebagian orang juga akan membantu tetapi terkadang individu mempertimbangkan terlebih dahulu untung rugi yang ia peroleh untuk dirinya sendiri apabila ia membantu. Beberapa fenomena diatas menunjukkan bahwa manusia yang dianggap sebagai makhluk sosial telah berubah menjadi manusia sebagai makhluk individual. Hal ini menunjukkan fenomena menurunnya perilaku prososial.

Fenomena menurunnya perilaku prososial dapat terjadi pada setiap lapisan masyarakat, dan tidak menutup kemungkinan fenomena ini terjadi juga pada siswasiswi yang masih bersekolah di Sekolah Dasar. Siswa-siswi sebagai calon penerus bangsa yang sedang mengalami proses belajar dituntut oleh masyarakat untuk memiliki tanggung jawab dalam bertingkah laku sesuai dengan norma masyarakat, berintelektual tinggi, dapat memberikan contoh yang baik dalam masyarakat sejak usia yang masih dini dalam berperilaku, seperti saling menolongdan bekerja sama.

Hal ini tersebut juga terjadi pada siswa-siswi di SD Negeri 2 Passo, Kecamatan Baguala, Kota Ambon.Fenomena menurunnya perilaku prososial pada siswa-siswi dapat dilihat dari rendahnya perilaku tolong-menolong, berbagi, dan bekerjasama antar siswa dengan penjaga sekolah, guru, dan sesama teman.Misalnya, saat teman yang lupa membawa bolpoint atau pensil ke sekolah siswa lain tidak akan 
meminjamkan pensilnya kepada teman yang lain, siswa mau menolong orang lain jika diberikan sesuatu. Perilaku tidak prososial juga tercermin dari sikap siswa diantaranya: jika ada pengemis maka siswa akan mengejek, ada juga beberapa siswa yang tidak suka berteman dengan teman-teman yang kurang mampu, sebaliknya mereka suka bermain dengan teman-teman yang sederajat.Contoh lainnya adalah perilaku menyontek ketika siswa sedang mengikuti test, berbohong ketika tidak masuk sekolah, siswa kurang bekerjasama dengan penjaga sekolah dalam menjaga kebersihan lingkungan sekolah.

Perilaku prososial merupakan salah satu bentuk perilaku yang muncul dalam kontak sosial, sehingga perilaku prososial adalah tindakan yang dilakukan untuk menolong tanpa mempedulikan motif-motif si penolong.Menurut Sears ${ }^{3}$,perilaku prososial adalah tindakan menolong yang sepenuhnya dimotivasi oleh kepentingan sendiri tanpa mengharapkan sesuatu untuk diri si penolong itu sendiri.Perilaku prososial ini pada umumnya diperoleh melalui proses belajar. Menurut Bal-Tal ${ }^{4}$ para psikolog menggunakan teori belajar sosial dalam mempelajari tingkah laku prososial yaitu melalui modelling dan reinforcement.

Adapun perilaku prososial yang muncul didasari beberapa faktor yang penting.Menurut penelitian sebelumnya terbukti bahwa hal yang berpengaruh terhadap perilaku prososial adalah kecerdasan emosi.Menurut Goleman ${ }^{5}$ kecerdasan emosi merupakan kemampuan mengenali perasaan diri sendiri dan perasaan orang lain, kemampuan memotivasi diri sendiri dan kemampuan mengelola emosi dengan baik pada diri sendiri dan dalam hubungannya dengan orang lain.Hal tersebut didukung oleh penelitian yang dilakukan oleh Marquez, Martin, dan Brackett ${ }^{6}$,yang menunjukkan bahwa siswa dengan kecerdasan emosi yang tinggi, lebih menunjukkan sikap prososial dan memiliki performasi yang lebih baik di sekolah.

Faktor lain yang juga berpengaruh dalam perilaku prososial pada siswa adalah faktor keluarga, dalam hal ini hubungan antara anak dan orang tua, karena faktor penentu utama dalam keberhasilan anak berperilaku prososial adalah ketika anak berinteraksi dengan lingkungan sosial yang lebih luas. Keluarga yang merupakan kelompok primer bagi anak memiliki peran penting dalam pembentukan dan arahan perilaku anak. Selain itu, terdapat cara untuk mengembangkan perilaku moral anak yang mengarah pada perilaku prososial, yaitu dengan orang tua berperan strategis untuk memberikan pola asuh yang terbaik bagi perkembangan moral anak. 
Salah satunya melalui pola asuh otoritatif dimana anak boleh mengemukakan pendapat sendiri, mendiskusikan pendangan-pandangan mereka kepada orang tua, menentukan dan mengambil keputusan.

Demikian pula dikatakan oleh Staub $^{7}$ bahwa hubungan afeksi antara anak dengan orang tua merupakan dasar bagi perkembangan kecenderungan perilaku prososial. Hubungan afeksi antara anak dan orang tua dapat tercermin dalam bentuk pola asuh yang diterapkan dalam keluarga.Grusec ${ }^{8}$ juga menyatakan bahwa pola asuh otoritatif menghasilkan anak mampu bersosialisasi, yaitu anak yang mampu bekerjasama, ramah, stabil secara emosional, dan bahagia.

Berdasarkan penelitian yang dilakukan oleh Diana Baumrind ${ }^{9}$, ditemukan bahwa pola asuh otoritatif memberikan kontrol perilaku pada anak tetapi juga menekankan pada kebebasan berpendapat, individualitas anak, dan mengembangkan tanggung jawab dan kompetensi sosial. Sementara ini kompetensi sosial meliputi perilaku berbagi dengan teman sebaya, menawarkan bantuan, melakukan pujian dan penghargaan kepada teman sebaya. Menurut Grusec ${ }^{10}$ juga dikatakan bahwa pola asuh otoritatif menghasilkan anak mampu bersosialisasi, yaitu anak yang mampu bekerjasama, ramah, stabil secara emosional, dan bahagia.

Pola asuh yang menerapkan disiplin dan sistem hukuman yang berlebihan, yang tidak berusaha berkomunikasi, memberikan penjelasan, pengertian, dan menerapan peraturan-peraturan yang konsisten, dan yang secara keterlaluan memarahi anak-anak cenderung menghalangi perkembangan perilaku prososial anak. ${ }^{11}$ Dengan adanya patokan-patokan yang jelas dan peluang untuk berlatih peran, maka anak akan mengerti suatu respon atau tindakan yang afektik sehingga tidak menduga-duga apa yang sebaiknya dilakukan. Perlu diperhatikan bahwa anak mempunyai kecenderungan untuk meniru, terutama perilaku orang tua atau guru harus memberikan contoh yang mencerminkan perilaku prososial pula.

Perbedaan jenis kelamin juga dapat memberikan pengaruh untuk seseorang mengemukakan perilaku prososial. Lehdonvirta, dkk., ${ }^{12}$ menyatakan bahwa gender mempengaruhi seseorang memberikan bantuan dengan cara-cara yang menyimpang dari peran-peran gender yang diharapkan. Caprara, dkk., ${ }^{13}$ mengemukakan perilaku prososial, sifat ramah, dan rasa empati perempuan dinilai lebih tinggi dari laki-laki. Sedikit berbeda dengan Carlo dan Randal ${ }^{14}$ dalam hasil penelitiannya menunjukkan 
bahwa laki-laki mempunyai kecenderungan yang lebih besar untuk terlibat dalam bentuk umum dari perilaku prososial dibandingkan perempuan. Berdasarkan hasil penelitian yang masih bertolak belakang, maka penulis ingin kembali melihat pengaruh gender terhadap perilaku prososial khusus pada siswa SD Negeri 2 Passo.

Faktor lain yang mempengaruhi perilaku prososail adalah usia. Caprara dan Steca $^{15}$ dalam penelitiannya selain melihat sisi gender, mereka juga melihat sisi usia dengan hasil bahwa orang-orang muda memiliki perilaku prososial yang tinggi dibandingkan orang dewasa. Berbeda dengan para sarjana di atas, Schwartz ${ }^{16}$ mengatakan bahwa orang yang lebih tua lebih mungkin untuk membantu orang lain dari pada orang-orang muda. Beberapa alasan menyebutkan bahwa dengan bertambahnya usia, maka individu akan dapat memahami atau menerima normanorma, lebih empati dan lebih dapat memahami nilai ataupun makna dari tindakan prososial yang ditunjukkan. ${ }^{17}$

Melihat berbagai fenomena dan hasil penelitian yang ada, maka penulis ingin melakukan penelitian lebih lanjut terhadap pengaruh kecerdasan emosi dan pola asuh otoritatif terhadap perilaku prososial anakusia 9 - 11 tahun pada siswa SD Negeri 2 Passo Kecamatan Baguala di Kota Ambon. Meskipun variabel yang dalam penelitian ini memiliki sejumlah kesamaan dengan penelitian-penelitian sebelumnya, tetapi yang membedakannya adalah subjek penelitian, dimana dalam penelitian ini adalah anak sekolah usia 9 - 11 tahun yang semuanya masih duduk di bangku Sekolah Dasar (SD). Selain itu, menurut Einsenberg ${ }^{18}$ bahwa masih sedikitnya penelitian tentang perilaku prososial terhadap anak-anak dan balita atau bayi, karena sejauh ini penelitian tentang perilaku prososial lebih banyak terpusat bagi para remaja.

Berdasarkan latar belakang permasalahan yang telah dikemukakan maka dalam penelitian ini dapat dirumuskan pokok permasalahan yang menjadi bahan kajian, yaitu: apakah terdapat pengaruh kecerdasan emosi dan pola asuh otoritatif secara simultan terhadap perilaku prososial anak usia $9-11$ tahun pada siswa SDNegeri 2 Passo Kecamatan Baguala di Kota Ambon. Tujuan penelitian ini adalah mengetahui pengaruh kecerdasan emosi dan pola asuh otoritatif secara simultan terhadap perilaku prososial anak usia 9 - 11 tahun pada siswa SD Negeri 2 Passo Kecamatan Baguala di Kota Ambon.

\section{LANDASAN TEORI}


Perilaku Prososial adalah tindakan yang memberikan keuntungan pada pihak lain yang terdiri dari berbagi, menyumbang, dukungan emosional atau belarasa, pertolongan dan kesediaan diri untuk membantu. ${ }^{19}$ Einsenberg dan Mussen ${ }^{20}$ juga mendefinisikan perilaku prososial sebagai tindakan sukarela yang dimaksudkan untuk membantu orang atau kelompok lain yang dilakukan dengan sukarela bukan dengan paksaan.Caprara, $\mathrm{dkk} .{ }^{21}$ mendefinisikan perilaku prososial sebagai perilaku gotong-royong, ramah-tamah, menolong, percaya, berbagi, dan empatik.

Dalam tulisan ini penulis menggunakan teori belajar tradisional dari Bandura. Dalam teori ini mengatakan bahwa hampir semua tingkah laku manusia dipelajari dan dibentuk oleh peristiwa yang terjadi di lingkungan seperti reward, punishment, dan modelling. Efek dari reward, danpunishment disebut reinforcement sedangkan modelling adalah proses belajar melalui proses observasi orang lain yang menolong. Ditinjau dari prespektif teori pembelajaran sosial tradisional, respon prososial diinterpretasikan sebagai konsekuensi dari reinforcement langsung (reward). Karakter moral diartikan sebagai kebiasaan belajar dan sifat baik yang dipelajari dari orang tua, guru, dan teman sebaya. Sebagai konsekuensi dari pengulangan pengalaman, anak belajar merespon mana yang menyebabkan pujian dari orang lain, misalnya orang tua, guru, dan teman sebaya.Bandura mengungkapkan bahwa perilaku seseorang adalah hasil dari interaksi faktor dalam diri (kognitif) dan lingkungan.Dapat disimpulkan juga bahwa perilaku prososial adalah hasil interaksi faktor kognitif (kecerdasan emosi) dan lingkungan (pola asuh otoritatif).

Dalam penelitian ini, penulis menggunakan aspek-aspek perilaku prososial Caprara danPastorelli ${ }^{22}$ sebagai berikut:Altruism, yaitu melibatkan perhatian tidak egois untuk orang lain. Hal ini melibatkan tindakan terhadap hal-hal sederhana dari keinginan untuk membantu.Kepercayaan, yaitu keyakinan terhadap seseorang atau sesuatu yang dapat diandalkan, baik, serta jujur.Ramah, yaitu individu yang ramah adalah individu yang berhati lembut dan selalu mengalah.

Salah satu faktor pembentuk perilaku prososial adalah kecerdasan emosi anak itu sendiri. Menurut Goleman ${ }^{23}$ kecerdasan emosi atau emotional intelligence merujuk pada kemampuan mengenali perasaan kita sendiri dan perasaan orang lain, kemampuan memotivasi diri sendiri, dan dalam hubungannya dengan dengan orang lain. Sullivan ${ }^{24}$ dalam disertasinya mendefinisikan kecerdasan emosi adalah 
kemampuan untuk memonitor perasaan dan emosidiri sendiri serta orang lain dengan menggunakan perasaan-perasaan itu untuk memandu pikiran dan tindakan seseorang.

Sullivan ${ }^{25}$ menjelaskan aspek-aspek kecerdasan emosi yang diadopsi dari Mayer, Salovey, dan Caruso ${ }^{26}$ sebagai berikut:

1. Persepsi Emosi (Emotional perception)

Persepsi emosi merupakan kemampuan individu untuk mengenali emosi, baik yang dirasakan diri sendiri maupun orang lain.

2. Memahami Emosi (Understanding emotions)

Memahami emosi merupakan kemampuan individu untuk memahami emosi yang dirasakan dan dapat menggunakan pengetahuan mengenai emosi yang dirasakan untuk mengetahui bagaimana penerapan dalam kehidupan sehari-hari.

3. Mengelola Emosi (Managing emotions)

Mengelola emosi merupakan kemampuan individu dalam menangani perasaan agar terungkap dengan tepat atau selaras, sehingga tercapai keseimbangan dalam diri individu.

Selain kecerdasan emosi, faktor pembentuk perilaku prososial adalah orang tua, sedangkan pola asuh yang mendukungnya adalah pola asuh demokratis atau autoritatif. Robinson, dkk., ${ }^{27}$ mengungkapkan bahwa orang tua yang mempunyai pola asuh otoritatif adalah orang tua yang dapat mengekspresikan kasih sayang, memberikan kenyamanan, memahami, membimbing anak dengan rasional, serta menghargai anak. Menurut Robinson, dkk., ${ }^{28}$ kehangatan dan orang tua otoritatif akan memiliki hubungan yang lebih kuat terhadap perilaku prososial anak-anak, misalnya membantu, berbagi dan menghibur.

Robinson dkk., ${ }^{29}$ menyatakan aspek-aspek pola asuh otoritatif adalah:

1. Memiliki Kehangatan dan Keterlibatan

Orang tua mengasuh anak dengan kehangatan dan keterlibatan antara orang tua dengan anak-anak itu sendiri. Keterlibatan dan kehangatan yang diberikan berupa kasih sayang, peduli dengan keadaan anak, mempunyai banyak waktu dengan anak.

2. Memiliki Nalar yang Baik 
Orang tua mengasuh anak dengan berpikir kritis dan kreatif, mempunyai argumentasi yang tepat, mampu memecahkan masalah, dan mampu mengambil keputusan.

\section{Berpartisipasi Demokratis}

Orang tua mengasuh anak dengan memprioritaskan anak dalam keputusan keluarga dan mempertimbangkan serta mendorong anak dalam mengekspresikan diri.

\section{Baik Hati}

Orang tua mengasuh anak dengan penuh kelembutan, santai, kesabaran, rasa hormat, dan humoris.

\section{METODE PENELITIAN}

Teknik pengambilan sampel dalam penelitian ini adalah teknik sampel jenuh. Seperti pendapat Arikuntoro ${ }^{30}$ yang mengatakan bahwa jika anggota subjek dalam populasinya hanya meliputi 100 hingga 150 atau kurang dari 100, dan dalam pengumpulan data menggunakan angket, maka sebaiknya subjek sejumlah itu diambil seluruhnya. Adapun sampel yang digunakan dalam penelitian ini adalah siswa yang berusia 9 - 11 tahundengan jumlah 107 siswa.

Variabel terikat yang digunakan dalam penelitian ini adalah perilaku prososial. Sementara variabel bebas berupa kecerdasarn emosi dan pola asuh otoritatif.

Defenisi operasional perilaku prososial adalah perilaku prososial sebagai perilaku gotong-royong, ramah-tamah, menolong, percaya, berbagi, dan empatik terhadap orang lain. ${ }^{31}$ Perilaku prososial akan diukur menggunakan skala prososial dari Caprara dan Pastorelli ${ }^{32}$ dengan aspek-aspek dari perilaku prososial diantaranya adalah altruisme (altruism), kepercayaan (trust), dan keramahan (agreeableness). Kecerdasan emosi adalah kemampuan untuk memonitor perasaan dan emosidiri sendiri serta orang lain dengan menggunakan perasaan-perasaan itu untuk memandu pikiran dan tindakan seseorang. Alat ukur kecerdasan emosi dalam penelitian ini menggunakan Emotional Intelligence Scale for Children (EISC), dengan aspek-aspek antara lain, persepsi emosi (perception emotion), memahami emosi (understanding emotions), dan mengelola emosi (managing emotions). ${ }^{33}$ Pola asuh otoritatif adalah 
orang tua otoritatif yang dapat mengekspresikan kasih sayang, memberikan kenyamanan, memahami, membimbing anak dengan rasional, serta menghargai anak. Pola asuh otoritatif akan diukur menggunakan skala pola asuh otoritatifdengan aspek-aspek dari pola asuh otoritatif diantaranya adalah memiliki kehangatan dan keterlibatan (warmth \& involvement), memiliki nalar yang baik (reasoning/induction), berpartisipasi demokratis (democratic participation), serta baik hati (natured/easy going). ${ }^{34}$

Hasil uji validitas dan reliabilitas pada perilaku prososial menunjukkan 20 aitem valid dan 5 aitem yang gugur dengan nilai alpha 0864. Hasil uji validitas dan reliabilitas pada kecerdasan emosi menunjukkan 26 aitem valid dan 14 aitem yang gugur dengan nilai alpha 0,893 . Hasil uji validitas dan reliabilitas pada pola asuh otoritatif menunjukkan 20 aitem valid dan 7 aitem yang gugurdengan nilai alpha0,886.

\section{HASIL PENELITIAN}

\section{Uji Asumsi (Normalitas, Multikolinieritas, Heteroskedastisitas, Lineritas)}

Dari perhitungan dengan SPSS 16.0, dengan uji Kolomogorov-Smirnov variabel perilaku prososial dan pola asuh otoritatif menunjukkan distribusi normal (p $>0,05)$ sedangkan variabel kecerdasan emosi tidak berdistribusi normal $(\mathrm{p}<0,05)$.

Secara keseluruhan dengan menggunakan metode statistik menunjukkan bahwa data dalam penelitian ini berdistribusi secara normal sehingga dapat dinyatakan bahwa asumsi normalitas dalam penelitian ini terpenuhi dan model regresi layak digunakan untuk menjadi alat untuk menganalisis perilaku prososial berdasarkan kecerdasan emosi dan pola asuh otoritatif pada anak usia 9-11 tahun pada siswaSD Negeri 2 Passokecamatan Bagualadi Kota Ambon.

Uji multikolinieritas menunjukkan tidak terjadi multikolinieritas, artinya bahwa tidak terdapat masalah multikolinieritas antar variabel bebas yaitu variabel pola asuh otoritatif dan kecerdasan emosi pada siswa SD Negeri 2 Passokecamatan Bagualadi Kota Ambon.Uji heteroskedastisitas menunjukkan tidak terjadi heteroskedastisitas sehingga model regresi dapat dipakai untuk memprediksi perilaku prososial berdasarkan kecerdasan emosi dan pola asuh otoritatif.Uji F menunjukkan $F_{\text {hitung }}$ sebesar 8,617 dengan nilai signifikansi sebesar $0,000(\mathrm{p}<0,05)$ dan $\mathrm{F}_{\text {tabel }}$ 
sebesar 3,08 ( $\alpha=5 \%)$ yang berarti ada pengaruh yang signifikan kecerdasan emosi dan pola asuh otoritatif terhadap perilaku prososial.

\section{Uji Hipotesis}

Berdasarkan hasil perhitungan analisis regresi berganda $F=8,617$, nilai signifikansi $0,000(\mathrm{p}<0,05)$ yang bermakna bahwa ada pengaruh kecerdasan emosi dan pola asuh otoritatif secara simultan (bersama) terhadap perilaku prososial siswaSD Negeri 2 Passokecamatan Bagualadi Kota Ambon. Dengan demikian hipotesis bahwa pengaruh kecerdasan emosi dan pola asuh otoritatif secara simultan (bersama) terhadap perilaku prososial, dapat diterima.

\section{ANOVA $^{b}$}

\begin{tabular}{llrrrrr}
\hline Model & & $\begin{array}{c}\text { Sum of } \\
\text { Squares }\end{array}$ & \multicolumn{1}{c}{$\begin{array}{c}\text { Mean } \\
\text { df }\end{array}$} & \multicolumn{1}{c}{ Square } & F & Sig. \\
\hline 1 & Regresi & 630.223 & 2 & 315.112 & 8.617 & $.000^{\mathrm{a}}$ \\
& Residual & 3803.179 & 104 & 36.569 & & \\
& Total & 4433.402 & 106 & & & \\
& & & & & & \\
& & &
\end{tabular}

a. Prediktor: (Konstant), Pola_Asuh_Otoritatif, Kecerdasan_Emosi

b. Variabel Terikat: Perilaku_Prososial

Koefisien determinasi (R Square) sebesar 0,142 yang bermakna bahwa 14,2\% variansi perilaku prososial dijelaskan oleh kecerdasan emosi dan pola asuh otoritatif. Hal ini juga bermakna bahwa 85,8\% variansi perilaku prososial dijelaskan oleh variabel lain selain kecerdasan emosi dan pola asuh otoritatif. 


\section{Jumlah $^{\text {b }}$ Model}

R Kuadrat yang

Model R R Kuadrat Disesuaikan Kesalahan Baku yang dikira-kira

\begin{tabular}{lllll}
\hline 1 & $.377^{\mathrm{a}}$ & .142 & .126 & 6.047
\end{tabular}

a. Prediktor: (Konstant), Pola_Asuh_Otoritatif, Kecerdasan_Emosi

b. Variabel Terikat: Perilaku_Prososial

\section{DISKUSI}

Berdasarkan hasil pengukuran analisis data di atas, diketahui bahwa kecerdasan emosi dan pola asuh otoritatif secara simultan mempunyai pengaruh yang positif dan signifikan terhadap perilaku prososial. Uji F (uji signifikansi simultan) dengan nilai $F_{\text {hitung }}$ sebesar 8,617 pada taraf signifikansi sebesar 0,000 ( $\left.p<0,005\right)$. Temuan ini juga didukung dengan pembuktian nilai $\mathrm{R}$ Square $\left(\mathrm{R}^{2}\right)$ sebesar 0,142 yang berarti $14,2 \%$ dari total varians perilaku prososial dapat dijelaskan secara simultan oleh kecerdasan emosi dan pola asuh otoritatif, sisanya sebesar 85,8\% dipengaruhi oleh variabel lain.

Kekuatan kecerdasan emosi dan pola asuh otoritatif sebagai pengaruh perilaku prososial pada siswa usia 9 - 11 tahun pada SD Negeri 2 Passo Kecamatan Baguala di Kota Ambon juga dapat dilihat melalui hasil analisis regresi yang menunjukkan tanda positif (searah), yang berarti semakin baik kualitas kecerdasan emosi dan pola asuh otoritatif akan berdampak pada peningkatan perilaku prososial. Penelitian Afolabi ${ }^{35}$ tentang kecerdasan emosi dan Altay dan Güre ${ }^{\text {a36 }}$ tentang pola asuh otoritatif secara terpisah mengungkapkan bahwa kecerdasan emosi dan pola asuh otoritatif masing-masing merupakan faktor internal dan eksternal yang mendorong siswa untuk berperilaku prososial terhadap orang lain.

Dilihat dari determinasi parsial diketahui bahwa kecerdasan emosi memberikan sumbangan efektif sebesar 4,8\% dengan determinasi parsial sebesar 0,181 atau dengan kata lain naik turunnya perilaku prososial yang mampu dijelaskan oleh kecerdasan emosi adalah sebesar 18\%. Nilai signifikansi kecerdasan emosi secara parsial sebesar 0,060 (p > 0,05) itu berarti variabel kecerdasan emosi secara parsial tidak berpengaruh secara signifikan terhadap perilaku prososial siswa SD Negeri 2 Passo. Hal ini mungkin disebabkan karena orang Ambon secara umum 
dikenal mempunyai temperamen tinggi, emosi mudah bergejolak dan mengalahkan nalar serta akal sehat. ${ }^{37}$ Hal ini senada dengan penelitian yang dilakukan oleh Afolabi $^{38}$ terhadap 200 mahasiswa di Nigeria, dimana bila kecerdasan emosi dipasangkan dengan keseluruhan variabel maka bernilai positif signifikan, tetapi bila diukur secara parsial dengan perilaku prososial maka tidak signifikan.

Psikolog Gustavo Carlo ${ }^{39}$ berkata, “Terdapat perbedaan individual yang besar dalam disposisi simpati, dan kita mengetahui bahwa anak-anak yang berkarakter simpatik umumnya berasal dari lingkungan yang hangat dan suportif. Anak-anak yang karakter simpatiknya tinggi juga cenderung menjadi anak yang memiliki penalaran moral yang cukup canggih serta cenderung baik dalam mengelola emosi mereka."

Hasil selanjutnya menunjukkan bahwa pola asuh otoritatif memberikan sumbangan efektif sebesar 9,4\% dengan determinasi parsial sebesar 0,282. Nilai signifikansi pola asuh otoritatif secara parsial sebesar 0,004 ( $p>0,05)$ itu berarti variabel pola asuh otoritatif secara parsial mempunyai hubungan secara signifikan dengan perilaku prososial. Penelitian ini konsisten dengan penelitian yang dilakukan oleh Altay dan Güre ${ }^{\mathrm{a} 40}$ yang menemukan bahwa ibu yang menunjukkan gaya pengasuhan otoritatif terhadap anak maka perilaku prososial anak lebih tinggi dibandingkan dengan ibu yang gaya pengasuhannya permisif. Selain itu, studi yang dilakukan Hastings, Mcshane, Parker, dan Ladha ${ }^{41}$ juga menemukan adanya kontribusi positif orang tua otoritatif terhadap perilaku prososial anak dalam hal ini ketika anak berinteraksi dengan orang asing.

Secara historis, pola asuh otoritatif sangat bertolak belakang dengan pola asuh yang diterapkan oleh sebagian orang tua di Ambon. Mayoritas ola asuh yang diterapkan sebagian orang tua di Ambon adalah pola asuh otoriter yaitu pola asuh yang berkarakter "keras" dan cenderung kasar. Hal ini terbentuk dalam konteks masyarakat "tangsi” (militer). Karakteristik yang demikian sudah membudaya bagi orang Ambon, karakteristik budaya "militeristik" yang sudah cukup lama mendominasi kehidupan sosial orang Maluku, termasuk Ambon, sejak keterlibatan orang Maluku sebagai tentara kolonial (KNIL). Inilah yang membuat para orang tua di Ambon mendidik anak dengan keras, baik secara verbal maupun non-verbal. Mungkin dengan realita pengasuhan sebagian orang tua di Ambon yang bertolak 
belakang dengan pengasuhan otoritatif inilah, sehingga dalam penelitian ini sumbangan efektif variabel pola asuh otoritatif terlihat lebih kecil dari pada sumbangan efektif variabel pola asuh demokratis pada penelitian yang dilakukan oleh Husada. ${ }^{42}$

Bumrid dan Black $^{43}$ dalam penelitiannya menemukan bahwa teknik-teknik asuhan orang tua yang otoritatif akan menumbuhkan keyakinan dan kepercayaan diri maupun mendorong tindakan-tindakan prososial, mandiri serta mampu membuat keputusan sendiri yang akan berakibat munculnya tingkah laku mandiri yang bertanggung jawab.

Sebagai informasi tambahan dari hasil penelitian ini, diketahui bahwa berdasarkan demografi jenis kelamin tidak ada perbedaan perilaku prososial antara laki-laki dan perempuan dilihat dari nilai signifikansi sebesar 0,982 (p > 0,05). Hal ini konsisten dengan penelitian yang dilakukan oleh Roberts dan Strayer $^{44}$ serta Hastings dkk., ${ }^{45}$ bahwa tidak ada perbedaan jenis kelamin dalam perilaku prososial. Hal ini menunjukkan bahwa perbedaan gender bukan faktor yang mempengaruhi tingkat perilaku prososial seseorang, khususnya siswa SD Negeri 2 Passo. Secara spesifik laki-laki dan perempuan memiliki kemampuan dan kesempatan yang sama untuk berperilaku prososial. Perilaku prososial antara laki-laki dan perempuan tidak berbeda karena dalam hal-hal tertentu perempuan lebih mudah memberikan pertolongan, namun pada situasi lain laki-laki juga akan lebih mudah bereaksi untuk memberikan pertolongan. ${ }^{46}$

Selain jenis kelamin, secara demografi usia bahwa ada perbedaan usia terhadap perilaku prososial dengan nilai Sig. 0,033 ( $p<0,05)$. Perbedaan tersebut pada kelompok usia 9 dan 10 tahun dengan nilai signifikansi sebesar 0,025 (p < 0,05). Penelitian ini didukung oleh penelitian yang dilakukan oleh Retnaningsih ${ }^{47}$ menunjukkan bahwa kelompok anak usia muda memiliki perilaku prososial, berbagi, bekerjasamadan menolong yang lebih tinggi dibanding kelompok anak yang usianya lebih tua.

\section{KESIMPULAN DAN SARAN}

a. Berasarkan hasil analisis dan pembahasan pada bab sebelumnya maka dapat disimpulkan bahwa kecerdasan emosi dan pola asuh otoritatif secara simultan mempunyai pengaruh terhadap perilaku prososial anak usia 9 - 11 tahun pada 
SD Negeri 2 Passo Kecamatan Baguala di Kota Ambon. Selain itu, berdasarkan hasil analisis maka tidak ada perbedaan jenis kelamin terhadap perilaku prososial, sedangkan untuk usia ada perbedaan perilaku prososial antar kelompok usia 9 dan 10 tahun pada siswa SD Negeri 2 Passo Kecamatan Baguala di Kota Ambon.

b. Penelitian ini masih terbatas, karena hanya meneliti hubungan kecerdasan emosi dan pola asuh otoritatif terhadap perilaku prososial. Dengan demikian masih ada variabel yang turut mempengaruhi perilaku prososial yang belum dijelaskan dan diteliti. Oleh karena itubebera rekomendasi yang diajukan untuk telaah atau penelitian selanjutnya yakni faktor biologis, budaya setempat, norma-norma, situasional, dan sebagainya.

\section{Endnotes:}

${ }^{1}$ D.O. Sears, J.I. Freedman, J.I., L.A. Peplau,Psikologi sosial jilid 2, Alih Bahasa:Michael Adyanto. (Jakarta: Erlangga, 1994).

${ }^{2}$ Lih. K. Törnblom, A. Kazemi (Eds.),Handbook of social resource theory: theoretical extensions, empirical insights, and social applications, critical issues in social justice, (New York: Springer Science Business Media, 2012).

${ }^{3}$ Sears, Psikologi sosial jilid 2.

${ }^{4}$ D.Bar-Tal,Prosocial behavior theory \& research,(New York: John-Willey, 1976).

${ }^{5}$ D. Goleman, Kecerdasan Emosional untuk Mencapai Puncak Prestasi,(Jakarta: Gramedia Pustaka Utama, 2005).

${ }^{6}$ Marquez, Martin, Brackett, (2006). "Relating emotional intelligence to social competence and academic achievement in high school student",Psichothema18, (2006)

${ }^{7}$ E. Staub, Positive social behavior and morality: social and personal influence, (New York: Academic Press, 1978).

${ }^{8}$ Lih. Mahmud,"Hubungan Antara Gaya Pengasuhan Orang Tua dengan Tingah LakuPrososial Anak",Jurnal Psikologi, 11(1), (2003), 1-10.

${ }^{9}$ D. Baumrind, "The Influence of Parenting Style on Adolescent Competence and Substance Use", The Journal of Early Adolescence, 11(1), (1991), 59-95

${ }^{10}$ Mahmud,"Hubungan Antara Gaya Pengasuhan Orang Tua dengan Tingah Laku Prososial Anak"

${ }^{11}$ P. D. Hastings, K. E. McShane, R. Parker, F. Ladha, "Ready to Make Nice: Parental Socialization of Young Sons' and Daughters' Prosocial Behaviors With Peers", The Journal of Genetic Psychology, 168(2), (2007).

${ }^{12}$ M.Lehdonvirta, V. Lehdonvirta, A. Baba, "Prosocial behaviour in avatar-mediated interaction: the influence of character gender on material versus emotional help-giving", $Q$ Emerald Group Publishing Limited, 19 (3), (2011).

${ }^{13}$ G.V. Caprara, dkk., "The Contribution of Agreebleness and Self-eficacy Beliefs to Prosociality", European Journal of Personality, 24(1), (2010).

${ }^{14}$ Carlo, G., \& Randal, B.A. (2002). The development of a measure of prosocial behaviorsfor late adolescents. Journal of Youth and Adolescence, 31 (1), 31-44.

${ }^{15}$ Caprara G.V., \& Steca, P. (2007). Prosocial agency: the contribution of values and self-efficacy beliefs to prosocial behavior across ages. Journal of Social and Clinical Psychology. 26 (2), 218-239. 
${ }^{16}$ Lih. Caprara, dkk., "The Contribution of Agreebleness and Self-eficacy Beliefs to Prosociality"

${ }^{17}$ Lih. T. Dayakisni, Hudaniah,Psikologi Social,(Malang: UniversitasMuhamadiah Malang, 2009).

${ }^{18}$ Lih. K. Dunfield, V.A. Kuhelmeier, L. O'Conell, E. Kelley, "Examining the Diversity of Prosocial

Behavior: Helping, Sharing, and Comforting in Infancy”,Journal of the International Socienty on Infant Studies, 16 (3)(2011).

${ }^{19}$ Fabes, R. A., \& Eisenberg, N. (1998). Meta-analyses of age and sex differences in children's and adolescents' prosocial behavior. Research Scientist Development, 3, 1-29.

${ }^{20}$ N. Eisenberg, P.H. Mussen,The root prososial in children,(New York: Cambridge University Press, 1989).

${ }^{21}$ G.V. Caprara, dkk., "Prosocial Foundations of Children's Academic Achievement" American Psycholigical Society, 11(4), (2000).

${ }^{22}$ G.V. Caprara, C. Pastorelli, "Early Emotional Instability, Prosocial Behavior, and Aggression:

Some Methodological Aspects”,European Journal of Personality. 7, (1993).

${ }^{23}$ Goleman, Kecerdasan Emosional untuk Mencapai Puncak Prestasi.

${ }^{24}$ A.K. Sullivan, "The emotional intelligence scale for children"Dissertation. (Virginia: Faculty of the Curry School of Education of Virginia, 1999).

${ }^{25}$ Sullivan, "The emotional intelligence scale for children"

${ }^{26}$ J.D. Mayer, P. Salovey, D.R. Caruso, "Emotional Intelligence: Theory, Findings, and Implication", Psychological Inquiry, 15(3), (2004).

${ }^{27}$ C. C. Robinson, dkk.,Psychometric support for a new measure of authoritative, authoritarian, and permissive parenting practices: cross-cultural connections, (Canada: Departemen of Education, 1996).

${ }^{28}$ Robinson, dkk.,Psychometric support for a new measure of authoritative, authoritarian, and permissive parenting practices: cross-cultural connections

${ }^{29}$ Robinson, dkk.,Psychometric support for a new measure of authoritative, authoritarian, and permissive parenting practices: cross-cultural connections

${ }^{30}$ S.Arikunto, Prosedur penelitian suatu pendekatan praktik. Edisi Revisi 6. (Jakarta: Rineka Cipta, 2006).

${ }^{31}$ Caprara, dkk., "The Contribution of Agreebleness and Self-eficacy Beliefs to Prosociality"

${ }^{32}$ Caprara, Pastorelli, "Early Emotional Instability, Prosocial Behavior, and Aggression: Some Methodological Aspects"

${ }^{33}$ Sullivan, "The emotional intelligence scale for children"

${ }^{34}$ Robinson, dkk.,Psychometric support for a new measure of authoritative, authoritarian, and permissive parenting practices: cross-cultural connections

${ }^{35}$ O.A. Afolabi, "Roles of Personality Types, Emotional Intelligence and Gender Differences on Prosocial Behavior",Psychological Thought,6 (1), (2013).

${ }^{36}$ F.B. Altay, A. Güre, "Relationship Among the Parenting Styles and the Social Competence and Prosocial Behaviors of the Children Who Are Attending to State and Private Preschools", Educational Sciences: Theory \& Practice, 12(4), (2012).

${ }^{37}$ R. Anwar, Sejarah kecil "Patite Histoire” Indonesia, (Jakarta: Buku Kompas, 2004).

${ }^{38}$ Afolabi, "Roles of Personality Types, Emotional Intelligence and Gender Differences on Prosocial Behavior"

${ }^{39}$ R. A. Baron, D. Byrne,Psikologi sosial, jilid 2 (Edisi 10), (Jakarta: Erlangga, 2005).

${ }^{40}$ Altay, Güre, "Relationship Among the Parenting Styles and the Social Competence and Prosocial Behaviors of the Children Who Are Attending to State and Private Preschools"

${ }^{41}$ Hastings, dkk., "Ready to Make Nice: Parental Socialization of Young Sons' and Daughters'

Prosocial Behaviors With Peers"

${ }^{42}$ Husada, A. K. (2013). Hubungan pola asuh demokratis dan kecerdasan emosi terhadap perilaku prososial pada remaja.Jurnal psikologi indonesia, 2 (3), 266-277.

${ }^{43}$ Lih. Kusjamilah, "Pengaruh Pola Asuh Otoriter terhadap Kedisiplinan dan Pengendalian Diri dari Remaja di Kampung Sinosaren Kelurahan Kemlayan Kecamatan Serangen",Skripsi (tidak dipublikasikan),(Surakarta: Univesitas Muhamadiyah Surakarta, 2001).

${ }^{44}$ W. Roberts, J. Strayer, "Empathy, Emotional Expressiveness, and Prosocial Behavior", Child development, 67 (2), (1996). 


\footnotetext{
${ }^{45}$ Hastings, dkk., "Ready to Make Nice: Parental Socialization of Young Sons' and Daughters' Prosocial Behaviors With Peers"

${ }^{46}$ Dayakisni, Hudaniah,Psikologi Social.

${ }^{47}$ Retnaningsih, Peranan Kualitas Aitachment, Usia dan Gender pada Perilaku Prososial, (Jakarta: Procceding Seminar Nasional PESAT, 2005).
}

\section{DAFTAR PUSTAKA}

Afolabi, O.A. "Roles of Personality Types, Emotional Intelligence and Gender Differences on Prosocial Behavior. Psychological Thought,6(1), 124-139, 2013.

Altay, F.B., \& Güre, A. "Relationship Among the Parenting Styles and the Social Competence and Prosocial Behaviors of the Children Who Are Attending to State and Private Preschools. Educational Sciences: Theory \& Practice, 12 (4), 2712-2718, 2012.

Anwar, R. Sejarah kecil “patite histoire” Indonesia. Jakarta: Buku Kompas, 2004.

Arikunto, S. Prosedur penelitian suatu pendekatan praktik. Edisi Revisi 6. Jakarta: Rineka Cipta, 2006.

Baumrind, D. "The Influence of Parenting Style on Adolescent Competence and Substance Use",The Journal of Early Adolescence, 11 (1),59-95, 1991.

Baron, R. A., Byrne, D. Psikologi sosial, jilid 2 (Edisi 10). Jakarta: Erlangga, 2005.

Bar-Tal, D. Prosocial Behavior Theory \&Research. New York: John-Willey, 1976.

Caprara, G.V., Alessandri, G., Giunta, L.A., Panerai, L., \& Einsenberg, N. "The Contribution of Agreebleness and Self-eficacy Beliefs to Prosociality",European Journal of Personality, 24 (1), 36-55, 2010.

Caprara, G.V., Barbaranelli, C., Pastorelli, C., Bandura, A., \& Zimbardo, P.G. "Prosocial Foundations of Children's Academic Achievement",American Psycholigical Society, 11 (4), 302-306, 2011.

Caprara, G.V.,\& Pastorelli, C. (1993). Early emotional instability, prosocial behavior, and aggression: some methodological aspects. European Journal of Personality. 7, 19-36.

Dayakisni, T., \& Hudaniah. Psikologi sosial. Malang: Universitas Muhamadiah Malang, 2009.

Dunfield, K., Kuhelmeier, V.A., O'Conell, L., \& Kelley, E.. "Examining the Diversity of Prosocial Behavior: Helping, Sharing, and Comforting in 
Infancy",Journal of the International Socienty On Infant Studies,16 (3), 227-247, 2011.

Eisenberg, N. \& Mussen. P.H. The root prososial in children. New York: Cambridge University Press, 1989.

Goleman, D. Kecerdasan emosional untuk mencapai puncak prestasi. Jakarta: Gramedia Pustaka Utama, 2005.

.Emotional intelligence (kecerdasan emosional - mengapa ei leih penting dari eq). Jakarta: Gramedia Pustaka Utama, 2000.

Hastings, P. D., Zahn-Waxler, C., Robinson, J., Usher, B., \& Bridges, D. "The Development of Concern for Others in Children with Behavior Problems",Developmental Psychology, 36 (5), 531-546, 2000.

Hastings, P. D., McShane, K. E., Parker, R., Ladha, F. "Ready to Make Nice: Parental Socialization of Young Sons' and Daughters' Prosocial Behaviors With Peers",The Journal of Genetic Psychology,168 (2), 177-200, 2007.

Karanci, B.P.L., Pastorelli, C., Einsenberg, N., Zuffianò, A., \& Caprara, G.V. (2013). "The Development of Prosociality from Adolescence to Early Adulthood: the Role of Effortful Control",Journal of Personality, 81 (3), 302-312, 2001.

Kusjamilah. "PengaruhPola Asuh Otoriter tehadap Kedisiplinan dan Pengendalian Diri dari Remaja di Kampung Sinosaren Kelurahan Kemlayan Kecamatan Serangen",Skripsi Sarjana(tidak dipublikasikan).Surakarta: Univesitas Muhamadiyah Surakarta, 2001.

Lehdonvirta, M., Lehdonvirta, V., \& Baba. A. "Prosocial Behaviour in Avatarmediated Interaction: the Influence of Character Gender on Material versus Emotional Help-giving",Q Emerald Group Publishing Limited, 19 (3), 165$173,2011$.

Mahmud. "Hubungan Antara Gaya Pengasuhan OrangTua dengan Tingkah Laku Prososial Anak."Jurnal Psikologi, 11 (1), 1-10, 2003.

Marquez, Martin, Brackett. "Relating emotional intelligence to social competence and academic achievement in high school student",Psichothema,18, 119123, 2006.

Mayer, J.D., Salovey, P., Caruso, D.R. "Emotional Intelligence: Theory, Findings, and Implication",Psychological Inquiry, 15 (3) ,197-215, 2004.

Retnaningsih. Peranan Kualitas Aitachment, Usia dan Gender pada Perilaku Prososial. Jakarta: Procceding Seminar Nasional PESAT, 2005.

Roberts, W. \& Strayer, J., "Empathy, Emotional Expressiveness, and Prosocial Behavior",Child development, 67 (2),449-470, 1996. 
Robinson, C.C., Mandleco, B., Olsen, S.F., \& Hart C.H.“Authoritative, authoritarian, and permissive parenting practices: development of a new measure"Psychlogical Reports, 77 819-830, 1995.

Robinson, C. C., Mandleco, B., Olsen, S. F., \& Hart C. H., Russell, A., Aloa, V., Nelson, D.A., Bazarskaya, N. Psychometric support for a new measure of authoritative, authoritarian, and permissive parenting practices: crosscultural connections. Canada: Departemen of Education, 1996.

Staub, E. Positive social behavior and morality: social and personal influence. New York: Academic Press, 1978.

Sullivan, A. K. The emotional intelligence scale for children. Dissertation. Virginia: Faculty of the Curry School of Education of Virginia, 1999.

Törnblom, K. \& Kazemi, A. (eds).Handbook of Social Resource Theory: Theoretical Extensions, Empirical Insights, and Social Applications, Critical Issues in Social Justice. New York: Springer Science Business Media, 2012. 